\title{
Assessing the effects of the modular approach in math learning on independent creativity of university students
}

\author{
Avaliando os efeitos da abordagem modular na aprendizagem da \\ matemática na criatividade independente de estudantes universitários
}

\section{Evaluar los efectos del enfoque modular en el aprendizaje de las matemáticas sobre la creatividad independiente de los estudiantes universitarios}

\author{
Elena A. Zubova ${ }^{1}$ (iD) \\ ${ }^{1}$ Department of Business Informatics and Mathematics, Industrial University of Tyumen, Tyumen, Russia. \\ Corresponding author: \\ Elena A. Zubova \\ Email: zubovaea@inbox.ru
}

How to cite: Zubova, E. A. (2021). Assessing the effects of the modular approach in math learning on independent creativity of university students. Revista Tempos e Espaços em Educação, 14(33), e16064.

http://dx.doi.org/10.20952/revtee.v14i33.16064

\begin{abstract}
Numerous teachers and researchers are studying the issue of improving the effectiveness of university education and offer innovative technologies to address this challenge. Modular learning is among the most relevant and productive teaching techniques. The paper examines how the modular approach in math learning contributes to the development of independent creativity of university students. The testing was performed at Tyumen Industrial University (Russia) among students of the Applied Geology program numbering 28 individuals in the control group and 27 individuals in the experimental group. The students were given a series of lectures to present new material that was later assimilated and reinforced during practical sessions through blocks and chains of preparatory and auxiliary tasks. To demonstrate their knowledge and grasping of the material, the students passed individual tests and exams. Statistical data were processed using Pearson's chi-squared test and the Wilcoxon signed-rank test. Based on the decision-making rule, the research confirms the hypothesis that the modular approach is more effective in forming students' independent creativity in math learning if compared with conventional education. The research results demonstrate that $92 \%$ of students in the experimental group set about solving advanced math problems, while in the control group this share was $61 \%$. The share of students in the experimental group who prepared research projects increased from $52 \%$ to $89 \%$, while in the control group their number decreased from $56 \%$ to $43 \%$. Among the avenues for further research is an attempt to implement applied research projects not only in math learning, but also in applied
\end{abstract}


subjects of study throughout the entire training period. The development of independent creativity of university students is expected to have a positive effect on their ability to absorb the material of other courses.

Keywords: Higher educational institution. Independent creativity. Math learning. Modular learning. Research projects.

\section{RESUMO}

Vários professores e pesquisadores estão estudando a questão de melhorar a eficácia da educação universitária e oferecer tecnologias inovadoras para enfrentar esse desafio. A aprendizagem modular está entre as técnicas de ensino mais relevantes e produtivas. $\mathrm{O}$ artigo examina como a abordagem modular na aprendizagem da matemática contribui para o desenvolvimento da criatividade independente dos estudantes universitários. $O$ teste foi realizado na Tyumen Industrial University (Rússia) entre alunos do programa de Geologia Aplicada com 28 indivíduos no grupo controle e 27 indivíduos no grupo experimental. Os alunos assistiram a um ciclo de aulas expositivas para apresentação de novos materiais que posteriormente foram assimilados e reforçados nas aulas práticas através de blocos e cadeias de tarefas preparatórias e auxiliares. Para demonstrar seu conhecimento e compreensão do material, os alunos foram aprovados em testes e exames individuais. Os dados estatísticos foram processados usando o teste qui-quadrado de Pearson e o teste dos postos sinalizados de Wilcoxon. Com base na regra de tomada de decisão, a pesquisa confirma a hipótese de que a abordagem modular é mais eficaz na formação da criatividade independente dos alunos na aprendizagem da matemática, se comparada com a educação convencional. Os resultados da pesquisa demonstram que $92 \%$ dos alunos no grupo experimental começaram a resolver problemas de matemática avançada, enquanto no grupo de controle essa participação foi de $61 \%$. A proporção de alunos no grupo experimental que elaborou projetos de pesquisa aumentou de $52 \%$ para $89 \%$, enquanto no grupo de controle seu número diminuiu de $56 \%$ para $43 \%$. Entre os caminhos para pesquisas futuras está uma tentativa de implementar projetos de pesquisa aplicada não apenas no aprendizado da matemática, mas também em disciplinas de estudo aplicadas ao longo de todo o período de treinamento. Espera-se que o desenvolvimento da criatividade independente dos estudantes universitários tenha um efeito positivo em sua capacidade de absorver o material de outros cursos.

Palavras-chave: Aprendizagem de matemática. Aprendizagem modular. Criatividade independente. Instituição de ensino superior. Pesquisar projetos.

\section{RESUMEN}

Numerosos profesores e investigadores están estudiando la cuestión de mejorar la eficacia de la educación universitaria y ofrecen tecnologías innovadoras para afrontar este desafío. El aprendizaje modular se encuentra entre las técnicas de enseñanza más relevantes y productivas. El artículo examina cómo el enfoque modular en el aprendizaje de las matemáticas contribuye al desarrollo de la creatividad independiente de los estudiantes universitarios. La prueba se realizó en la Universidad Industrial de Tyumen (Rusia) entre los estudiantes del programa de Geología Aplicada con 28 individuos en el grupo de control y 27 individuos en el grupo experimental. Se impartió a los alumnos una serie de conferencias para presentar nuevo material que posteriormente fue asimilado y reforzado durante las sesiones prácticas a través de bloques y cadenas de tareas preparatorias y auxiliares. Para demostrar su conocimiento y comprensión del material, los estudiantes aprobaron pruebas y exámenes individuales. Los datos estadísticos se procesaron mediante la prueba de chicuadrado de Pearson y la prueba de rango con signo de Wilcoxon. Con base en la regla de toma de decisiones, la investigación confirma la hipótesis de que el enfoque modular es más efectivo para formar la creatividad independiente de los estudiantes en el aprendizaje de las matemáticas en comparación con la educación convencional. Los resultados de la investigación demuestran que el 
92\% de los estudiantes del grupo experimental se dedicó a resolver problemas matemáticos avanzados, mientras que en el grupo de control esta proporción fue del $61 \%$. La proporción de estudiantes en el grupo experimental que prepararon proyectos de investigación aumentó de 52\% a $89 \%$, mientras que en el grupo de control su número disminuyó de $56 \%$ a $43 \%$. Entre las vías para la investigación adicional se encuentra un intento de implementar proyectos de investigación aplicada no solo en el aprendizaje de las matemáticas, sino también en las materias de estudio aplicadas a lo largo de todo el período de formación. Se espera que el desarrollo de la creatividad independiente de los estudiantes universitarios tenga un efecto positivo en su capacidad para absorber el material de otros cursos.

Palabras clave: Aprendizaje matemático. Aprendizaje modular. Creatividad independiente. Institución de educación superior. Proyectos de investigación.

\section{INTRODUCTION}

Today's society needs highly-skilled personnel who are competitive in the labor market and able to creatively and independently deal with any problem (Zubova, 2020). The source of such specialists is higher education institutions. Rapid changes in the socio-economic sphere are transforming the approach to learning into an integrative one (Gardanova et al., 2020). The teaching processes of both fundamental natural-technical courses and the humanities are being constantly reassessed. This also affected math learning. Students often do not possess skills essential for solving math problems, which indicates a fail in vocational training.

It is worth noting that the traditional learning process at the university has a clear structure leaving little attention to students' independent creativity, which is the fundamental quality of a future specialist in the assimilation of the mathematical apparatus. It is also of necessity in solving applied problems in senior courses in related disciplines, and in the professional realization of a future specialist. The social effect of the development of creative activity is inextricably linked with the general socio-economic situation.

It is widely believed that the use of modular technologies positively affects the formation of independent creativity in math learning (Ioannou et al., 2015; Shcherbatykh, Dvoryatkina, \& Smirnov, 2020). This statement underlies our hypothesis. The paper aims to develop a toolkit for forming university students' independent creativity in math learning using modular technologies. To attain the stated purpose, we formulate the following objectives: to analyze the relevant experience in forming independent creativity in math learning among university students; to identify the forms and methods of modular education; to devise a methodology for forming students' independent creativity in math learning using modular technologies and test its effectiveness.

\section{LITERATURE REVIEW}

The effectiveness of mastering courses is greatly influenced by the motives of students' activities, their awareness of the importance of the material being studied, and a steady interest in the subject as the volume of assimilated information increases (Lawanto \& Stewardson, 2013; Grebennikova et al., 2018; Litau, 2018). Academic performance is also affected by numerous factors, such as family income, parents qualification and interaction with teachers (Kamal \& Ahuja, 2019; Shakil Ahamed, Mahmood, \& Rahman, 2017).

The issue of independent and creative activity was addressed by a number of researchers, and all of them proposed their own definition of the concept of independent activity. According to Afanasyev (Afanasyev, Povarenkov, \& Smirnov, 2002), a student's creative activity is actions of an individual ensuring the involvement in the process of creating something new, which implies the intra- and intersystem transfer of knowledge and skills into novel situations and changing the way 
of action when solving educational problems. Ammosova (2008) sees intellectual creativity as a process of creating something subjectively new based on the ability to generate original ideas and act unconventionally. Lerner (1976) interprets creativity as a type of activity aimed at creating qualitatively new values that are important for personality formation.

According to Gusev, Matrosov and Nasybulina (1993), creativity is characterized by the following features: originality, fluency, flexibility of thought, curiosity, the ability to transform, etc. Dewey (1997) singled out the criteria characterizing independent creativity: students create something new while relying on their knowledge, theoretical and practical experience, intuition, imagination and due to their abstract actions; they pose and tackle problems, and identify brandnew non-standard methods for dealing with challenges; students are independent in finding a way or several ways of resolving problems, and are capable of applying their knowledge in unusual situations. Independent creativity allows students to eliminate ready-made templates and established attitudes, and sets the tone of educational activity as a flexible and search-based process.

When generating conditions for students' creative activity, they first should be given an opportunity to do some work copying a role model (Hendry \& Tomitsch, 2014). While imitating, an analogy is first used, and only in the process of completing typical tasks, students gradually move away from copying; they learn by analogy, which is quite an effective method. Independent activity can act as both common and creative reproduction. The latter results in the creation of something new and original that conveys individual inclinations, abilities and experience of the student: an original proof of a theorem or atypical solution to the proposed problem. In addition, collaborative work can encourage the exchange of ideas and stimulate creative problem solving (Hansen, 2021).

In the literature on psychology and pedagogy, independence is interpreted as an individual capability to act without the external interference. This feature is closely related to autonomy, selfcriticism, self-control, and self-confidence (Fridman, 1987). Lately, independent learning has been defined as a learning method and a form of organizing student activities; a type of cognitive activity; a means for the teacher to involve the student in independent cognitive and practical activity, purposefully organize and manage this activity allowing for students' competence level. In didactics, the development of students' independence and creative activity in learning occurs from the lower level to the higher level (Brushlinsky, 1983; Stepanov, 2001; Lerner, 2001; Bespalko, 2009):

- reproducing (performing exercises according to the role model);

- variable (when solving problems, a comparative analysis is used, and the most effective of the available methods is chosen);

- partial search (ability to perform comparison, analysis, synthesis, and abstraction, independently organize one's own activity, combine generalized methods to solve more complex problems, find several methods and choose the most rational ones). At this level, there are elements of creativity, and control and self-control of learning outcomes take a significant place;

- creative (independent setting of a problem, designing a plan, putting forward a hypothesis and testing it, conducting independent research). This work is most conveniently and fully done when organizing modular learning (undertaking research projects, participating in academic competitions, etc.).

The task of the teacher is to ensure the transition of the student to the next stage of development (Afanasyev, 1996). Genkulova (2004) proposed a set of methodological support measures for individual independent work of students considering their individual abilities. Pólya (1991) identified heuristic techniques that embraced providing a clear understanding of the proposed problem, drawing up a solution plan, implementing it, testing and making a critical evaluation of the outcome, and composing new combinations. Kashapov (2006) demonstrated the formation of students' cognitive independence on the basis of an educational-informational complex on mathematics. 
When designing modular learning in mathematics, we support the position of Yutsyavichene (2001), taking into account all the listed principles, excluding dynamism, since in our case there is no need in it. In this research, modular learning in mathematics is premised on the principles of the applied nature, separation of individual elements from the content, effectiveness or efficiency of knowledge and their systems, flexibility, awareness of perspective, versatility of methodological consulting, and parity.

\section{METHODOLOGY}

We hypothesize that students' independent creativity will improve if focusing on the application of modular math learning principles. The hypothesis was tested using the following experiment: in the 2018-2020 academic years, two groups of first-year students of the Applied Geology program of the Tyumen Industrial University (Russia) were selected; they numbered 28 students in the control group and 27 students in the experimental group. The initial level of their math skills was established by the scores of the unified state examination at the end of Grade 11.

The modular approach constituted the basis of math learning at the university. Student independent work implied studying additional literature on the module's topic (textbooks, teaching aids, etc.), doing homework, preparing research projects, etc. Seminar programs were designed to be held in a lesson preceding the midpoint assessment. In advisory classes, independent work suggested implementing additional tasks consisting of several parts and designed to be fulfilled over a long period of time, and working with scientific and educational literature. The results of studying the module's material were summed up at the final lecture.

Statistical data were processed using Pearson's chi-squared test $\chi^{2}$ (Ventcel, 2014) and the Wilcoxon signed-rank test (Gmurman, 2016). The former was used to process data at the early stages of learning (clarification of significant differences in the experimental and control groups in terms of the level of acquired mathematical skills), and the latter was applied when assessing the extent to which the students' independent creativity was formed.

To clarify the formed differences in the level of acquired mathematical skills among the control and experimental groups, the students took a test "Application of mathematics in future profession".

The test covered several problems of different complexity levels concerning the use of math in future professional activity. At the first level, the ability to apply the acquired knowledge (rules and algorithms) was checked. The second level provided for using knowledge under changed conditions, but within the framework of proven techniques and the possibility of utilizing known algorithms. The last, third, level of complexity included problems focused on demonstrating knowledge under highly modified conditions, requiring the skills in performing search and research activities. The advanced tasks required a creative approach to be employed.

The students of the experimental group studied the module program according to a set of methodological techniques, studied additional literature, carried out research projects, and made reports at seminars. The students of the control group studied the same material, but the learning process was organized using the traditional education means. Then, the quality of knowledge and independent creative activity of the students was assessed on the basis of the indicators of their independent creativity. The math problems were aimed at identifying the students' skills to draw logical conclusions (analyze, synthesize), generalize, find various methods of solution and compare them, perform deductive and inductive reasoning. The students' skills and knowledge involving a creative approach were tested. Each of the skills was assessed using a score system.

Based on the results demonstrated by the students, it was supposed to test the hypothesis about the absence of differences in the level of math knowledge. Hypothesis $\mathrm{H}_{0}$ suggests the following: forming independent creativity on the basis of the modular approach in math learning produces the same results as with the traditional education, with the alternative hypothesis $\mathrm{H}_{1}$. 
Hypothesis $\mathrm{H}_{1}$ implies that the students from the experimental and control groups are different in their math skills, and developing independent creativity allows getting better results on the basis of modular math learning than with traditional education.

To test hypothesis $\mathrm{H}_{0}$, the Wilcoxon signed-rank test was used. 28 students in the control group and 27 students in the experimental group were tested. Since the number of the students in the experimental group is less than in the control group $(27<28)$, then, according to the Wilcoxon signed-rank test, it is necessary to calculate the observed value of the criterion $W_{\text {obs }}$ (the sum of the serial numbers of the smaller sample), the lower critical point $\varpi_{l . s . p}(1)$ and the upper critical point $\varpi_{\text {h.s.p }}(2)$.

$$
\varpi_{l . s . p}=\left[\frac{\left(n_{1}+n_{2}+1\right) n_{1}-1}{2}-z_{k p} \sqrt{\frac{n_{1} n_{2}\left(n_{1}+n_{2}+1\right)}{12}}\right],
$$

where $\mathrm{n}_{1}$ and $\mathrm{n}_{2}$ are volumes of smaller and larger samples, respectively; $z_{s . p}$ are the critical point of the two-sided critical region, which is derived from the table of the Laplace Transforms from the equality

$$
\begin{aligned}
& \qquad\left(z_{\text {s.p }}\right)=(1-2 \alpha) / 2 \text { if } \alpha=0,05 . \\
& \varpi_{\text {h.s.p }}=(n+n+1) \times n-\varpi_{\text {l.s. }} .
\end{aligned}
$$

Next, we compare $W_{o b s}$ and $\varpi_{\text {h.s.p }}$. If $W_{o b s}>\varpi_{\text {h.s. }}$, then $\mathrm{H}_{\mathrm{o}}$ is rejected.

\section{RESULTS}

It has been experimentally tested how effective the methodology for forming students' independent creativity using modular learning is, and its performance has been analyzed.

Table 1 shows the percentage of the students by the quality of knowledge, preparing projects, presenting at seminars and student conferences, and completing an advanced complexity test. These results give reason to believe that the use of a set of methodological techniques of modular learning in math classes exerts a positive effect on the quality of student learning, their attitude to additional classes, and the formation of their independent creativity.

Table 1. Observational data on the overall academic performance of the students.

\begin{tabular}{lccccc}
\hline \multicolumn{1}{c}{ Group } & $\begin{array}{c}\text { Number of } \\
\text { students }\end{array}$ & $\begin{array}{c}\text { Knowledge } \\
\text { level, } \%\end{array}$ & $\begin{array}{c}\text { Research } \\
\text { projects, } \%\end{array}$ & Conferences, \% & $\begin{array}{c}\text { Advanced complexity } \\
\text { test chosen, \% }\end{array}$ \\
\hline Control & 28 & 71 & 59 & 10 & 61 \\
Experimental & 27 & 89 & 91 & 29 & 92 \\
\hline
\end{tabular}

$92 \%$ of the students in the experimental group and only $61 \%$ of them in the control group chose to do an advanced complexity test. Considering such indicators, we can assert that this model for developing students' independent creativity in math classes is effective.

Table 2 presents the number of students who successfully completed the test. It is noteworthy that, unlike the control group, the students from the experimental group were

\begin{tabular}{|c|c|c|c|c|c|c|c|c|c|c|}
\hline \multirow{2}{*}{ Group } & \multicolumn{10}{|c|}{ Task No. } \\
\hline & 1 & 2 & 3 & 4 & 5 & 6 & 7 & 8 & 9 & 10 \\
\hline Experimental & 27 & 25 & 24 & 25 & 21 & 20 & 21 & 20 & 11 & 7 \\
\hline Control & 28 & 23 & 26 & 24 & 19 & 18 & 24 & 21 & 8 & 6 \\
\hline Complexity & \multicolumn{4}{|c|}{ First level } & \multicolumn{3}{|c|}{ Second level } & \multicolumn{3}{|c|}{ Third level } \\
\hline
\end{tabular}
interested, conscious and creative about solving all the math problems.

Table 2. Testing results. 
The results of independent creative activity of the students who took part in preparing research projects and their presentation are given in table 3.

Table 3. Assessment of the creative component in the students' academic performance.

\begin{tabular}{cccc}
\hline Course & Group & $\begin{array}{c}\text { Number of students who } \\
\text { completed their projects }\end{array}$ & Total share, \% \\
& Experimental & 19 & 52 \\
& Control & 15 & 56 \\
II & Experimental & 25 & 89 \\
& Control & 12 & 43 \\
\hline
\end{tabular}

As seen from table 3, the number of the students in the experimental group working on the creative level is almost twice the number in the control group. The share of students who finished their research projects in the experimental group increased from $52 \%$ to $89 \%$, whereas their share in the control group, on the contrary, decreased from $56 \%$ to $43 \%$. Compared to the control group, the students of the experimental group had an opportunity to form independent creativity when studying the module material: searching for a solution plan and its implementation, studying additional literature, comparing facts, selecting the appropriate material, assimilating and applying it. Thus, we can conclude that the modular approach to math learning had a positive effect on the level of students' independent creativity.

At the next stage, statistical testing of data was performed.

For the accepted significance level $\alpha=0.05$ and the number of degrees of freedom $v=9 \mathrm{vs}$, the empirical value $\chi^{2} \approx 16.9$ was computed. The result of the processing showed that the critical statistical value is greater than the empirical one (16.9>2.7). Hence, in accordance with the Pearson's chi-squared test conditions, there was no reason to reject hypothesis $H_{0}$, that is, the groups initially exhibited similar mathematical skills. Thus, testing indicated that at this stage there were no significant differences between these groups in terms of the level of intellectual and mathematical knowledge.

Then, the testing was performed in accordance with the Wilcoxon signed-rank test. We calculated $W_{o b s}=980$, then found $\Phi\left(z_{s . p}\right)=0.45$ for $\alpha=0.05$, and determined $z_{s . p}=0.64$. After that, we found $\varpi_{l . s . p}=581.89$ and $\varpi_{\text {h.s. }}=768.11$. The inequality $W_{o b s}>\varpi_{h . s . p}(980>768.11)$ proves to be true. Therefore, according to the decision-making rule, the null hypothesis was rejected at the level $\alpha=0.05$, and the alternative hypothesis $\mathrm{H}_{1}$ was adopted. It can be concluded that modular learning is more effective in forming students' independent creativity than the traditional education.

The effectiveness of the proposed methodology of modular learning was demonstrated through the results of the exams in the end of the second (final) math course (Table 4). It allows evaluating the improvement in the students' academic performance in math.

Table 4. Math exam results.

\begin{tabular}{cccc}
\hline \multirow{2}{*}{ Group } & \multicolumn{3}{c}{ Second course (\%) } \\
\cline { 2 - 4 } & Excellent & Good & Satisfactory \\
\hline Experimental & 81 & 18 & 1 \\
Control & 52 & 35 & 13 \\
\hline
\end{tabular}

The results confirmed the necessity to use the modular approach to forming the students' independent creativity since it meets their personal needs. As a result, the following positive changes were observed: better mastering of new material (based on the outcomes of current, intermediate and final exams); the students' increased independence in solving math problems; their active participation in preparing projects and reports, as well as presenting at seminars. 
Moreover, the number of students who chose to do the advanced test increased. This indicates the students' growing interest and independent creativity.

Having analyzed the results of solitary and creative work when studying math, we found that it allowed the students: to absorb new information at an individual pace; to comprehend the relationship between the discipline's fields and other related branches of knowledge; to link the topic under study with those discussed earlier; to make generalizations and transfer knowledge to new situations; to get the freedom to search, which stimulates their creative activity; to acquire knowledge in the creation process; and to form independent creativity. Thus, the students managed to effectively master the new knowledge and showed interest in all topics of the math course. Most students from the control group did not grasp the full set of skills required for effective solving of math problems and did not display a considerable interest in the course material.

The formation of students' independent creativity is expected to have a positive effect on the study of other disciplines. The possible avenue for further research is to implement research projects of applied nature not only in math learning, but also in applied subjects throughout the entire education period.

\section{CONCLUSION}

Adequate staffing suggests employees having specific competencies that are formed through both the grasping of specialized knowledge and the ability to creatively solve the relevant problems. The modern education can apply both the traditional and integrated approach, where the modular principle is possible to be implemented. In the course of the research, we conducted a comparative analysis of learning methods at a university and studied the modular approach. The research results demonstrate that modular math learning is more effective in comparison with the traditional education. According to empirical data, the number of students in the experimental group working at a creative level is almost twice the number of students in the control group. The share of students who completed their research projects in the experimental group increased from $52 \%$ to $89 \%$, whereas their share in the control group decreased from $56 \%$ to $43 \%$. The students of the experimental group, in contrast to the control group, were able to form independent creativity while studying the course material. $92 \%$ of students in the experimental group set about solving advanced math problems, while in the control group this share was $61 \%$. Hence, the modular approach to forming students' independent creativity when learning math is effective and contributes to the development of professional motivation. The effective mastering of the course is greatly affected by the students' motives, their awareness of the importance of the material being studied, and a steady interest in the course as the volume of information increases. We anticipate that the students' independent creativity formed with help of the modular approach will positively influence their ability to master other disciplines.

Authors' Contributions: Zubova, E. A.: conception and design, acquisition of data, analysis and interpretation of data, drafting the article, critical review of important intellectual content. The author has read and approved the final version of the manuscript.

Ethics Approval: Not applicable.

Acknowledgments: Not applicable.

\section{REFERENCES}

Afanasyev, V. V. (1996). Formation of students' creative activity in the process of solving mathematical problems. Ushinsky YSPU.

Afanasyev, V. V., Povarenkov, Yu. P., \& Smirnov, E. I. (2002). Training a math teacher: Innovative approaches. Gardariki. 
Ammosova, N. V. (2008). Formation of the creative personality of primary schoolchildren by means of mathematics. AGPU.

Bespalko, V. P. (2009). Elements of learning methodology. Pedagogika.

Brushlinsky, A. V. (1983). Psychology of thinking and problem learning. Znanie.

Dewey, J. (1997). Psychology and pedagogy of thinking. Sovershenstvo.

Fridman, L. M. (1987). Pedagogical Experience through the Eyes of a Psychologist: A Teacher's Book. Prosveschenie.

Gardanova, Z., Ponkratov, V., Kuznetsov, N., Nikitina, N., Dudnik, O., Latypova, E., \& Shcherbatykh, S. (2020). A model for optimizing the structure of teaching techniques for distance learning in the Russian higher education system. Journal of Open Innovation: Technology, Market, and Complexity, 6(4), 1-21. https://doi.org/10.3390/joitmc6040147

Genkulova, O. V. (2004). Methodological support of individual independent work using the method of learning algebra and the principles of analysis of future math teachers. Cand. ped. sci. diss. Yaroslavl, Russia.

Gmurman, V. E. (2016). Theory of probabilities and math statistics. Visshaya Shkola.

Grebennikova, V. M., Bonkalo, T. I., Nikitina, N. I., Gardanova, Z. R., \& Grebennikov, O. V. (2019). A study of personality factors in inclusive vocational education: The case of Russia. Espacios, 40(44), 25.

Gusev, V. A., Matrosov, V. L., \& Nasybulina, A. K. (1993). Math learning and the holistic formation of a student's personality (pp. 38-47). In MSPU Scientific Works. Series: Natural Sciences. Prometey.

Hansen, E. K. S. (2021). Students' agency, creative reasoning, and collaboration in mathematical problem solving. Mathematics Education Research Journal. https://doi.org/10.1007/s13394-021-00365-y

Hendry, G. D., \& Tomitsch, M. (2014). Implementing an exemplar-based approach in an interaction design subject: Enhancing students' awareness of the need to be creative. International Journal of Technology and Design Education, 24(3), 337-348. https://doi.org/10.1007/s10798-013-9256-6

Ioannou, A., Vasiliou, C., Zaphiris, P., Arh, T., Klobučar, T., \& Pipan, M. (2015). Creative Multimodal Learning Environments and Blended Interaction for Problem-Based Activity in $\mathrm{HCl}$ Education. TechTrends, 59, 47-56. https://doi.org/10.1007/s11528-015-0839-9

Kamal P., \& Ahuja S. (2019). Academic Performance Prediction Using Data Mining Techniques: Identification of Influential Factors Affecting the Academic Performance in Undergrad Professional Course. In: N. Yadav, A. Yadav, J. Bansal, K. Deep, \& J. Kim (Eds.). Harmony Search and Nature Inspired Optimization Algorithms, Advances in Intelligent Systems and Computing, 741. Springer, Singapore. https://doi.org/10.1007/978-981-13-0761-4 79

Kashapov, M. M. (2006). Psychology of professional thinking. PER SE.

Lawanto, O., \& Stewardson, G. (2013). Students' interest and expectancy for success while engaged in analysis- and creative design activities. International Journal of Technology and Design Education, 23, 213-227.

https://doi.org/10.1007/s10798-011-9175-3

Lerner, I. Ya. (1976). Didactic system of learning methods. Znanie.

Lerner, I. Ya. (2001). Didactic basics of learning methods. Pedagogika.

Litau, E. Y. (2018, April 25-26). Cognitive science as a pivot of teaching financial disciplines (pp. 72-80). Proceedings of the 31st International Business Information Management Association Conference, IBIMA 2018: Innovation Management and Education Excellence through Vision 2020, Milan.

Pólya, G. (1991). How to Solve It. Kvantor.

Shakil Ahamed, A. T. M., Mahmood, N. T., \& Rahman, R. M. (2017). Prediction of Academic Performance During Adolescence Based on Socioeconomic, Psychological and Academic Factors. In: D. Król, N. Nguyen, \& K.Shirai (Eds.). Advanced Topics in Intelligent Information and Database Systems. ACIIDS 2017. Studies in Computational Intelligence, 710. Springer, Cham. https://doi.org/10.1007/978-3-319-56660-3 7

Shcherbatykh, S. V., Dvoryatkina, S. N., \& Smirnov, E. I. (2020). Parameters and structure of neural network databases for assessment of learning outcomes. International Journal of Criminology and Sociology, 9, 1638-1648.

Stepanov, V. D. (2001). Intensifying extracurricular work in mathematics in high school. Prosveschenie.

Ventcel, E. S. (2014). Theory of probabilities. Nauka.

Yutsyavichene, P. A. (2001). Principles of modular learning. Soviet Pedagogy, 1, 55-60. 
Zubova, E. A. (2020). Developing engineering student creativity in mathematics classes at technical university. International Transaction Journal of Engineering, Management \& Applied Sciences \& Technologies, 11(13), $19-28$.

Received: 17 June 2021 | Accepted: 13 August 2021 | Published: 28 August 2021

This is an Open Access article distributed under the terms of the Creative Commons Attribution License, which permits unrestricted use, distribution, and reproduction in any medium, provided the original work is properly cited. 